\title{
Assistance in Making Form Design and Recording Medical Records for Toddlers at Posyandu Kutilang, Sukowiyono Village, Kec. Padas, Ngawi Regency
}

\author{
Wahyu Wijaya Widiyanto $^{1 *}$, Sri Wulandari ${ }^{2}$, Artika Fristi Firnawati ${ }^{3}$ \\ 1,2,3 Bachelor of Applied Health Information Management, Polytechnic Indonusa Surakarta \\ 1,2,3 Jl. K.H Samanhudi No.31, Bumi, Kec. Laweyan, Surakarta City, Central Java 57149. \\ * Corresponding Author: \\ Email: wahyuwijaya@poltekindonusa.ac.id
}

\begin{abstract}
.
In the activities of Posyandu Kutilang, Sukowiyono Village, Kec. Padas, Kabupaten Ngawi, a health check was carried out by a health center health worker, but there was no form of a toddler's medical record that could be used to document the results of a health examination. The target of this community service activity is the Posyandu Kutilang posyandu participants. Guidance and consultation was carried out by Lecturers and Students of the Department of Medical Records and Health Information at the Indonusa Polytechnic Surakarta when accompanying cadres of Posyandu Kutilang, Sukowiyono Village, Kec. Padas, Ngawi Regency in documenting the health history of toddler participants. The assistance provided includes how to fill out medical record forms for toddlers, what items must be filled in, and how to manage forms. Health checks are only recorded in the agenda book for elderly examinations belonging to the Mobile Puskesmas, so that the participants of Posyandu Kutilang, Sukowiyono Village, Kec. Padas, Kabupaten Ngawi cannot monitor the results of monthly health checks. Results of Assistance in Making Form Design and Recording Medical Records for Toddlers at Posyandu Kutilang, in the hall of Posyandu Kutilang, Sukowiyono Village, Kec. Padas, Ngawi Regency was attended by 11 people. Activities started according to the agreed schedule. The training participants participated in the activity enthusiastically because they felt that this activity had a role in administrative order through the implementation of recording in the form / resume of toddler medical records.
\end{abstract}

Keywords: Toddlers, Designs, Forms, Posyandu, Medical Records.

\section{INTRODUCTION}

According to the World Health Organization, WHO [1]-[3] a person is called elderly (elderly) if they are 60-74 years old. According to Law Number 29 of 2004 concerning Medical Practice, it is stated that what is meant by a medical record is a file containing notes and documents concerning patient identity, examination, treatment, actions and other services that have been provided to patients. The process of organizing medical records begins at the time the patient is received, followed by recording the patient's medical data by a doctor or dentist or other health worker who provides direct health services to the patient. Followed by the management of medical record files which include organizing, storing and releasing files from storage areas to serve requests / borrowings. Medical records are a very important part of a health 
service facility because medical records contain all information related to the patient's medical history while receiving health care. In addition, medical records are the main source in producing health information that can be used as material for decision making in a health service facility.

In order to produce accurate and useful health information, good data collection tools are also needed. The tool used for data collection is a medical record form. A good medical record form can be used to collect complete data as needed and can be processed into useful information. In accordance with the Regulation of the Minister of Health of the Republic of Indonesia Number 269 / MENKES / PER / III / 2008 [4], [5]concerning medical records, it is stated that every facility that provides health services is obliged to manage medical records in order to improve the quality of health services. The main source of health administration activities starts from medical record files, therefore medical records are used as the starting base of evidence in court and are a legal means of defense in case of various litigation problems. In the activities of Posyandu Kutilang, Sukowiyono Village, Kec. Padas, Ngawi District, carried out a health check-up by a health center health worker, but there is no medical record form that can be used to document the results of a health examination. The results of the examination are only recorded in the toddler examination agenda book owned by the Mobile Puskesmas, so that the posyandu participants for toddlers cannot monitor the results of their health checks. In connection with these problems, the Department of Medical Records and Health Information at Indonusa Polytechnic Surakarta carries out community service activities in the form of providing guidance, assistance and consultation in the design of special medical record forms for toddlers. By coaching the posyandu health care form / resume design for toddlers, it is hoped that the Posyandu health resume form / resume in Kutilang, Sukowiyono Village, Kec. Padas, Ngawi Regency can be used to document and monitor the results of child health checks on an ongoing basis at Posyandu Kutilang activities, Sukowiyono Village, Kec. Padas, Ngawi District which is implemented by Mobile Health Center Officers.

\section{METHODS}

The place for the implementation of the Assistance Services for Form Designing and Recording of Medical Records for Toddlers at Posyandu Kutilang, Sukowiyono Village, Kec. Padas, Ngawi Regency in the hall of Posyandu Kutilang, Sukowiyono Village, Kec. Padas, Ngawi Regency. The overall timing of the PkM program will be held on Friday, January 252019 at 09.00 - 13.00 WIB for 3 days. The target of this activity is Kader Posyandu Kutilang, Sukowiyono Village, Kec. Padas, Ngawi Regency.

The stages of the PkM program activities can be seen in the following table 1 below: 
Table 1. Activity step

\begin{tabular}{|c|c|}
\hline \multicolumn{2}{|c|}{ Preparation phase } \\
\hline Pre-Survey & $\begin{array}{l}\text { Identification of problems experienced by } \\
\text { Partners }\end{array}$ \\
\hline Establishment of the PkM Team & $\begin{array}{l}\text { Team formation is tailored to the type of } \\
\text { expertise to solve partner problems }\end{array}$ \\
\hline Proposal Making & $\begin{array}{l}\text { Making a proposal is used to write down } \\
\text { the problems faced by the partners then } \\
\text { write down the solutions to the problems } \\
\text { given }\end{array}$ \\
\hline \multicolumn{2}{|c|}{ Preparation phase } \\
\hline Team \& Partner coordination & $\begin{array}{l}\text { Planning for program implementation in } \\
\text { conceptual, operational and job } \\
\text { descriptions of the Team \& Partners }\end{array}$ \\
\hline $\begin{array}{l}\text { Preparation of Training Tools \& } \\
\text { Materials }\end{array}$ & $\begin{array}{l}\text { Preparation of tools and making workshop } \\
\text { materials }\end{array}$ \\
\hline \multicolumn{2}{|c|}{$\begin{array}{c}\text { Implementation Stage } \\
\text { (Activities carried out in the Hall of Posyandu Kutilang, Sukowiyono Village, } \\
\text { Padas District, Ngawi Regency) }\end{array}$} \\
\hline $\begin{array}{l}\text { 1. Providing education to health } \\
\text { workers / health service providers at } \\
\text { the Toddler Posyandu activities in } \\
\text { Sukowiyono Village, Kec. Padas, } \\
\text { Ngawi District in managing toddler } \\
\text { medical record forms according to } \\
\text { standards } \\
\text { 2. Provide training in form / resume } \\
\text { health for toddlers according to } \\
\text { standards }\end{array}$ & Presentation \\
\hline \multicolumn{2}{|c|}{ Program Evaluation } \\
\hline $\begin{array}{l}\text { Conducted to determine the success rate } \\
\text { of PkM }\end{array}$ & $\begin{array}{l}\text { The success indicators seen from the } \\
\text { participants can be: } \\
\text { 1. Increased knowledge of health } \\
\text { workers / health service providers on } \\
\text { the activities of the Toddler Posyandu } \\
\text { in Sukowiyono Village, Kec. Padas, } \\
\text { Ngawi District in managing toddler } \\
\text { medical record forms according to } \\
\text { standards } \\
\text { 2. The creation of a form / resume for }\end{array}$ \\
\hline
\end{tabular}




\begin{tabular}{|l|l|}
\hline \multirow{1}{*}{\begin{tabular}{|l|} 
Reporting \\
basis
\end{tabular}} \\
\hline $\begin{array}{l}\text { toddler health according to standards } \\
\text { and documented health checks for the } \\
\text { elderly at Posyandu Kutilang } \\
\text { activities, Sukowiyono Village, Kec. } \\
\text { Padas, Ngawi Regency on an ongoing }\end{array}$ \\
\hline Reporting & $\begin{array}{l}\text { Report preparation is done as a form of } \\
\text { accountability for the implementation of } \\
\text { the program for publication }\end{array}$ \\
\hline
\end{tabular}

There are several approaches used in implementing the program, including:

\section{Exposure}

The presentation is used as an initial explanation of the theme to be presented at $\mathrm{PkM}$, it consists of program materials How to fill in toddler medical record forms, what items are required to be filled in the form, and how to manage forms [6]

\section{Democracy}

Demonstrations are used as a medium to explain technically to the $\mathrm{PkM}$ participants

\section{Discussion}

The discussion includes matters that become technical and non-technical obstacles related to PkM activities.

PkM partners are Posyandu Kutilang cadres, Sukowiyono Village, Kec. Padas, Ngawi Regency. Partner participation in the PkM program includes:

1. Partners act as activity participants

2. Partners are given the opportunity to discuss and provide solutions in accordance with the PkM theme

3. Partners have full involvement in PkM activities

\section{RESULT AND DISCUSSION}

Assistance in Making Form Design and Recording Medical Records for Toddlers at Posyandu Kutilang, Sukowiyono Village, Kec. Padas, Ngawi Regency in the hall of Posyandu Kutilang, Sukowiyono Village, Kec. Padas, Ngawi Regency. Participants of this activity are Posyandu Kutilang cadres, Sukowiyono Village, Kec. Padas, Ngawi Regency. The following table 2 of training activities schedule is:

\section{Theory \\ Opening \\ Welcome}

Material I: Providing education to health workers / health service providers at the Toddler Posyandu activities in Sukowiyono Village, Kec. Padas, Ngawi District in managing toddler medical record forms according to standards 
break

Material II: Providing training on toddler health forms / resume according to standards and discussions

\section{Closing}

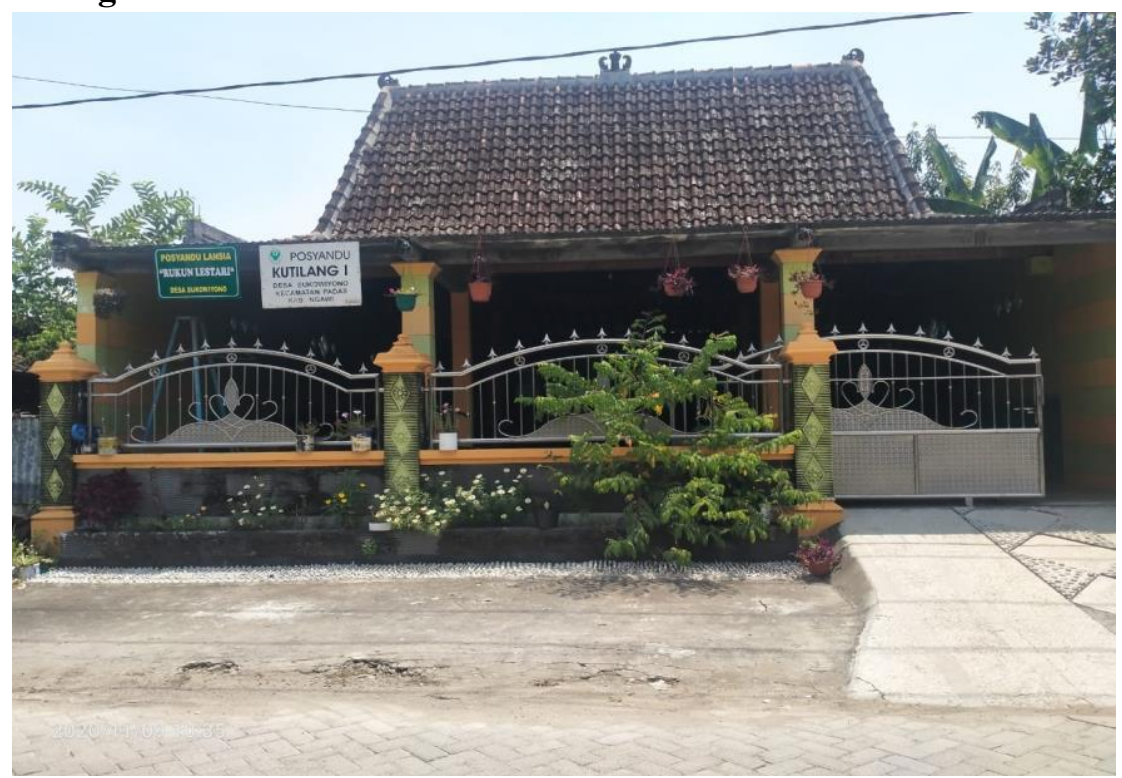

Fig. 1. Posyandu for Toddlers in Sukowiyono Village, Kec. Padas, Ngawi Regency

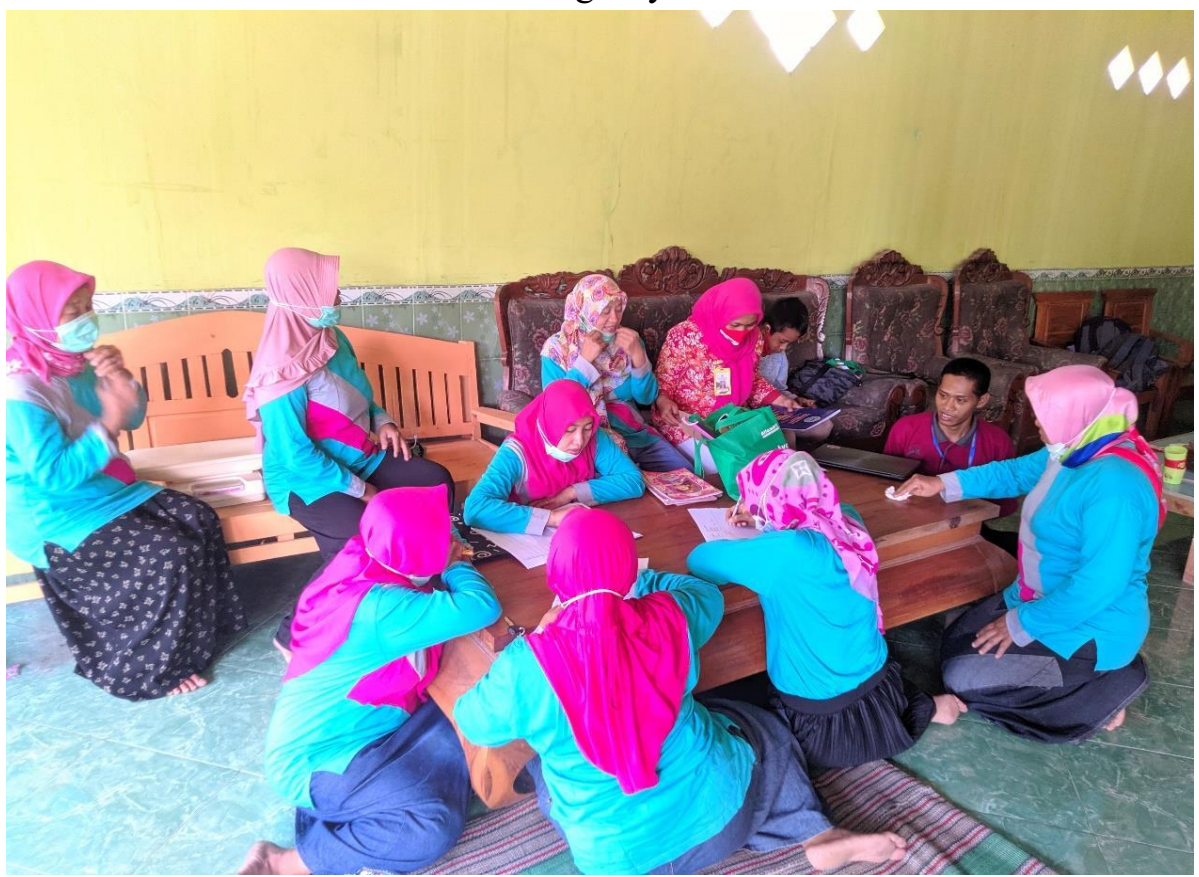

Fig. 2. Discussion regarding form design 


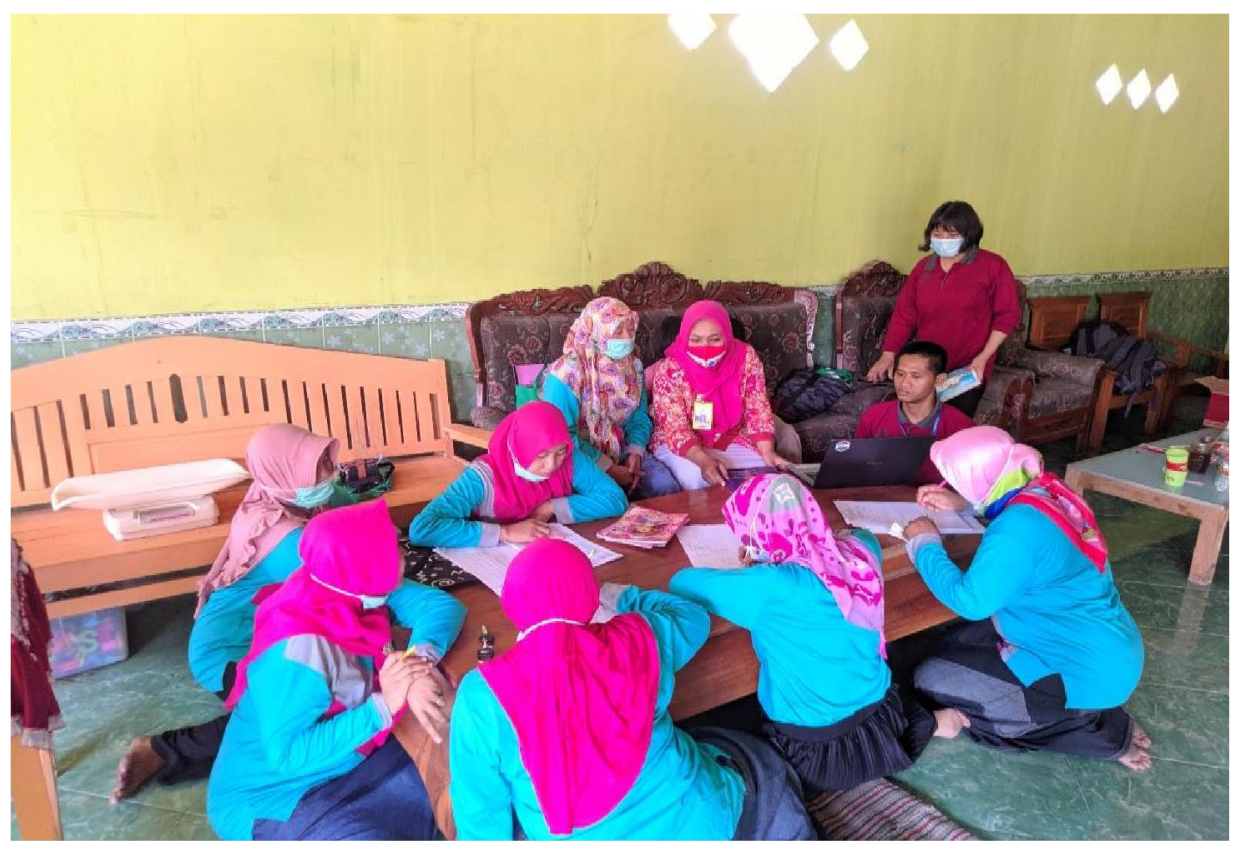

Fig. 3. Explanation of how to fill in a good form design

Assistance in Making Form Design and Recording Medical Records for Toddlers at Posyandu Kutilang, Sukowiyono Village, Kec. Padas, Ngawi Regency in the hall of Posyandu Kutilang, Sukowiyono Village, Kec. Padas, Ngawi Regency was attended by 11 people. Activities started according to the agreed schedule. The training participants participated in the activity enthusiastically because they felt that this activity had a role in administrative order through the implementation of recording in the form / resume of toddler medical records [1], [7], [8].

\section{CONCLUSION}

The final conclusion from the implementation of PkM Assistance for Form Designing and Recording of Medical Records for Toddlers at Posyandu Kutilang, Sukowiyono Village, Kec. Padas, Ngawi Regency in the hall of Posyandu Kutilang, Sukowiyono Village, Kec. Padas, Ngawi Regency are: 1. The training goes according to a previously scheduled plan. 2. Participants can find out about the form design and how to fill it out. 3. Participants can increase knowledge in orderly administration of medical record documents. The suggestion from this activity is that the cadres of Posyandu Kutilang, Sukowiyono Village, Kec. Padas, Kabupaten Ngawi makes it a habit to collect data in medical record forms that are made.

\section{ACKNOWLEDGMENTS}

Thanks to the officers, cadres, and participants of the Kutilang Posyandu, Sukowiyono Village, Kec. Padas, Ngawi Regency who helps and is willing to be a 
partner in the implementation of this research and at the Surakarta Indonusa Polytechnic which provides full facilities for this activity.

\section{REFERENCES}

[1] W. W. Widiyanto and S. Wulandari, "Accuracy Implementation of Medical Record Management Information System with Waterfall Design System and ISO 9126," Asian J. Res. Comput. Sci., vol. 6, no. 2, pp. 36-45, 2020.

[2] N. A. Anggraini, A. Mufidah, D. S. Putro, and I. S. Permatasari, "Pendidikan kesehatan pertolongan pertama pada kecelakaan pada masyarakat di kelurahan dandangan," $J$. Community Engagem. Heal., vol. 1, no. 2, pp. 21-24, 2018.

[3] A. E. Maghfiroh and A. Siwiendrayanti, "Hubungan Cuci Tangan, Tempat Sampah, Kepemilikan SPAL, Sanitasi Makanan dengan Demam Tifoid,” J. Pena Med., vol. Vol. 6, no. No. 1, p. Hal. 34-45, 2016.

[4] PERMENKES RI No 269/MENKES/PER/III/2008, “permenkes ri 269/MENKES/PER/III/2008,” Permenkes Ri No 269/Menkes/Per/Iii/2008, vol. 2008. p. 7, 2008.

[5] R. A. Khoiriyah, Daimatul Rahajo, Yulliarto Setia, "Rancang Bangun Sistem Informasi Klinik dengan Layanan Online Report Menggunakan Pascal IDE dan MYSQL pada Klinik Mitra Anda," Electr. - J. Rekayasa dan Teknol. Elektro Ranc., vol. 8, no. 1, p. 8, 2014.

[6] R. Manajemen, F. Dan, and D. Formulir, "Kesehatan Umum Di Puskesmas Sunyaragi Kota Cirebon,” J. Pengabdi. Kpd. Masy. Poltekkes Kemenkes Tasikmalaya, pp. 1-7.

[7] E. Santosa, E. Maria Rosa, and F. Tiara Nadya, "Kelengkapan Pengisian Berkas Rekam Medis Pelayanan Medik Rawat Jalan Dan Patient Safety Completeness of Charging Medical Services Medical Record File Outpatient and Patient Safety in Rsgmp Umy," vol. 66, 2013.

[8] D. M. A. D. Prawiradirjo, B. H. Kartiko, and G. Feoh, "Perancangan Sistem Informasi Rekam Medis Elektronik Rawat Jalan Berbasis Web Di Klinik Gigi Bright Smiles Bali,” J. Teknol. Inf. dan Komput., vol. 4, no. 1, pp. 31-41, 2018. 